\title{
Omalizumab treatment in brittle asthma
}

\author{
Roman Skiepko, Ziemowit Zietkowski, Urszula Skiepko, Wojciech Budny, Mateusz Lukaszyk, \\ Anna Bodzenta-Lukaszyk
}

Department of Allergology and Internal Medicine, Medical University of Bialystok, Poland Head of Department: Prof. Anna Bodzenta-Lukaszyk MD, PhD

Postep Derm Alergol 2014; XXXI, 1: 36-38 DOI: 10.5114/pdia.2014.40658

\begin{abstract}
Asthma is a heterogeneous disease with variable characteristics such as lung function, symptoms and control, body weight, pattern of inflammation, and response to treatment. Brittle asthma is one of clinical phenotypes of asthma with unclear pathogenic mechanisms and appropriate treatment. Analysis of 2 described cases suggests that omalizumab could be useful in the treatment of brittle allergic asthma.
\end{abstract}

Key words: brittle asthma, omalizumab.

\section{Introduction}

Omalizumab is a humanized monoclonal anti-lgE antibody developed for the treatment of IgE-mediated diseases, including asthma. So far the influence omalizumab treatment on brittle asthma is not known.

\section{Case reports}

\section{Case 1}

We describe a 46-year-old female with 30 years' history of type 1 brittle asthma. Despite continuous therapy with a combination of $\beta$, agonist, high doses of inhaled corticosteroids (ciclesonide $640 \mathrm{mg}$ twice daily), and montelukast, her asthma was not well controlled. The patient suffered from death-threatening asthma exacerbations 4-5 times per year. These events usually began with fast progressive paroxysmal dyspnea with a low effect of short acting $\beta_{2}$ agonist (SABA), wheezes in the chest and severe decrease in peak expiratory flow (PEF). For a few hours the patient had progressive dyspnea, tachycardia, disturbances of consciousness and finally she lost her consciousness. Typically, the emergency rescue (ER) team in physical examination found: Glascow Coma Scale (GCS) 6 pct, cyanosis, fast shallow respiration $30 / \mathrm{min}$, silent vesicular murmur, heart rate (HR) 140/min, blood pressure $70 / 50 \mathrm{~mm} \mathrm{Hg}$. After treatment according to GINA guidelines, the patient regained consciousness after several minutes and returned to stable condition after 3-6 days of hospitalization. The patient underwent neurological and cardiological examination to diagnose the cause of faint. No other cause, except severe asthma exacerbation has been found.

In stable condition her pulmonary function test showed: forced expiratory volume in $1 \mathrm{~s} /$ forced vital capacity $\left(\mathrm{VEV}_{1} / \mathrm{FVC}\right)$ ratio of $54.12 \%$; $\mathrm{FEV}_{1}-1.31 \mathrm{l}, 55.7 \%$ of predicted value, FVC -2.17 I, $78.5 \%$ of predicted value, daily variation of PEF $>40 \%$, and exhaled nitric oxide (FeNO) concentration of 24 ppb. A Skin Prick Test (SPT) with common allergens was positive for dust mites. The patient had lgE level of $66 \mathrm{IU} / \mathrm{ml}$, slgE to Dermatophagoides pteronyssinus: $26 \mathrm{IU} / \mathrm{ml}$, class 4 . The patient did not achieve asthma symptom control despite adhering to current guidelines-based standards of therapy and had been qualified to omalizumab therapy.

According to the manufacturer's recommendations, the treatment consisted of $150 \mathrm{mg}$ of omalizumab in subcutaneous injections given every 4 weeks.

After a few months, the patient achieved a significant improvement in asthma control test score and symptoms, reduction in rescue medication use, significant decrease in acute asthma episodes and hospitalizations. In the following 60 months of omalizumab treatment, the patient did not experience severe exacerbations accompanied with loss of consciousness. There were no emergency or hospital admissions for asthma and only 3 courses of systemic steroids during 5 years were administered during asthma exacerbations over that period.

Address for correspondence: Roman Skiepko MD, PhD, Department of Allergology and Internal Medicine, Medical University of Bialystok, 24 A Sklodowska-Curie St, 15-276 Bialystok, Poland, phone: +48 8574683 73, fax: +48 8574686 01, e-mail: roman_skiepko@op.pl Received: 28.11.2013, accepted: 6.01.2014. 

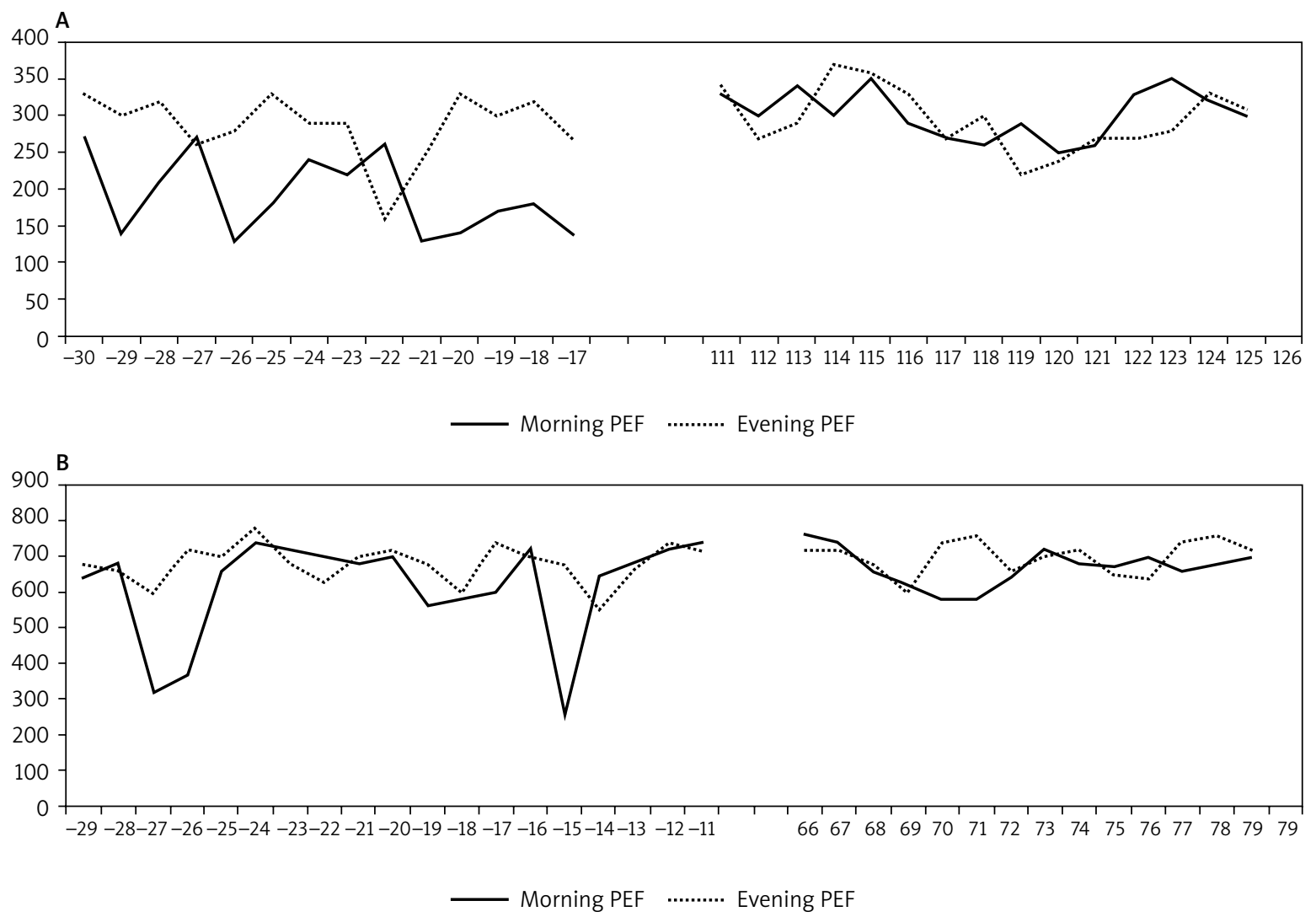

Figure 1. The PEF before and during omalizumab treatment: A - case 1, B - case 2

\section{Case 2}

We report the case of a 26 -year-old female, with 10 years' history of asthma. She was treated with inhaled corticosteroids (fluticasone $2000 \mu \mathrm{g} /$ day), $\beta_{2}$ agonist, and montelukast $10 \mathrm{mg} /$ day. Despite treatment with a high dose of inhaled corticosteroids (ICS) and montelukast, she suffered from frequent, sudden asthma attacks (2-3/ month) with a decrease of PEF $>40 \%$. These episodes required treatment with high doses of SABA and sometimes systemic corticosteroids. After several hours, symptoms used to disappear and PEF increased. We diagnosed brittle asthma type 2 .

In stable condition her pulmonary function test showed: $\mathrm{FEV}_{1} / \mathrm{FVC}$ ratio of 101.8\%; FEV -3.91 l, 100.5\% of predicted value, FVC -4.51 l, $101.8 \%$ of predicted value, PEF $650 \mathrm{l} / \mathrm{min}$, FeNO concentration of $120 \mathrm{ppb}$. A SPT with common allergens was positive for dust mites. The patient had lgE level of $460 \mathrm{IU} / \mathrm{ml}$, slgE to D. pteronyssinus: $>100 \mathrm{lU} / \mathrm{ml}$, class 6 .

To improve asthma control, omalizumab treatment was added to the maintenance therapy. According to the manufacturer's recommendations, $300 \mathrm{mg}$ of omalizumab was administered every 2 weeks.

After 16 weeks of treatment, the patient achieved a significant improvement in asthma control. Over the next 16 months of treatment with omalizumab, she did not suf- fer from asthma exacerbation episodes with a PEF decrease $>40 \%$ and administration of systemic corticosteroids.

\section{Discussion}

Asthma is a heterogeneous disease with variable characteristics such as lung function, symptoms and control, body weight, pattern of inflammation, and response to treatment. Brittle asthma is one of clinical phenotypes of asthma. Two types of brittle asthma can be identified. Type I brittle asthma is characterized by more than $40 \%$ of diurnal variation in PEF for more than $50 \%$ of time maintained over a period of at least 150 days despite considerable medical therapy. Type II brittle asthma is characterized by sudden acute attacks occurring in less than $3 \mathrm{~h}$ on the background of apparent normal airway function or well-controlled asthma [1].

The possible mechanism of omalizumab efficacy in brittle asthma is unknown, probably because risk factors of developing this clinical asthma phenotype are unclear. In type I of brittle asthma, several factors including atopy, relative immunoglobulin deficiency, impaired hypoxic driver or ventilatory response, nutrient deficiency, psychological factors, food intolerance, autonomic imbalance, relative resistance to the anti-inflammatory action may be important [2,3]. For patients with the disease of type 2 there are no published data on risk factors. 
More than $90 \%$ of brittle asthma patients are atopic [4]. Omalizumab prevents binding of IgE to high-affinity (FcERI) or low affinity (FceRII) receptors on several inflammatory cell types. It inhibits initiation of inflammatory cascade after exposure to an allergen, thus prohibiting induction of cell activation and release of inflammatory mediators, which contribute to acute and chronic symptoms of asthma [5, 6]. Treatment with anti-lgE significantly reduces the airway eosinophilia in the induced sputum, epithelium and submucosal layers, decreases levels of circulating cytokines IL-13, IL-5, serum eosinophil cationic protein (ECP) and eotaxin, decreases the concentrations of RANTES and endothelin-1 (ET-1) in exhaled breath condensate, and decreases concentration of FeNo [7-9].

The prevalence of brittle asthma is not well known. Data from the West Midlands Brittle Asthma Register in the UK suggest that it occurs in $0.05 \%$ of all asthmatics. Although the brittle asthma is a rare clinical phenotype of the disease, it is an important medical and socioeconomic issue. Patients with brittle asthma require frequent hospital admissions, emergency attendances and ventilation in acute attacks. Both groups have an increased risk of death from asthma during episodes of acute asthma attacks [10]. Morbidity is also increased by therapy side-effects, notably from oral corticosteroids and $\beta_{2}$ agonists.

To our knowledge, it is the first publication on efficacy of omalizumab in patients with brittle asthma. Analysis of the described cases suggests that omalizumab, despite so far unclear pathogenic mechanisms, could be useful in the treatment of brittle allergic asthma.

\section{Acknowledgments}

The data were presented as a poster at EAACI-WAO Congress, 22-26 June 2013, Milan, Italy

\section{References}

1. Ayres JG, Miles JF, Barnes PJ. Brittle asthma. Thorax 1998; 53: 315-21.

2. Ayres JG, Thompson RA. IgG sub-class deficiency in brittle asthma and in patients with recurrent infective exacerbations of asthma. Respir Med 1997; 91: 464-9.

3. Miles JF, Cayton RM, Tunnicliffe WS, et al. Increased atopic sensitization in brittle asthma. Clin Exp Allergy 1995; 25: 1074-82.

4. Miles JF, Cayton RM, Tunnicliffe WS, Ayres JG. Increased atopic sensitization in brittle asthma. Clin Exp Allergy 1995; 25: 1074-82.

5. Hanf G, Brachmann I, Kleine-Tebbe J, et al. Omalizumab decreased IgE-release and induced changes in cellular immunity in patients with allergic asthma. Allergy 2006; 61: 1141-4.

6. Platts-Mills TA. The role of immunoglobulin E in allergy and asthma. Am J Respir Crit Care Med 2001; 164: 1-5.

7. Noga O, Hanf G, Kunkel G. Immunological and clinical changes in allergic asthmatics following treatment with omalizumab. Int Arch Allergy Immunol 2003; 131: 46-52.
8. Zietkowski Z, Skiepko R, Tomasiak-Lozowska MM, et al. RANTES in exhaled breath condensate of patients with severe persistent allergic asthma during omalizumab therapy. Int Arch Allergy Immunol 2011; 154: 25-32.

9. Zietkowski Z, Skiepko R, Tomasiak-Lozowska MM, Bodzenta-Lukaszyk A. Anti-IgE therapy with omalizumab decreases endothelin-1 in exhaled breath condensate of patients with severe persistent allergic asthma. Respiration 2010; 80: 534-42.

10. Ayres JG, Jyothish D, Ninan T. Brittle asthma. Paediatr Respir Rev 2004; 5: 40-4. 